\title{
Redaksjonen svarer:
}

De beste fagartiklene blir ofte til gjennom tverrfaglig samarbeid. Tidsskriftets redaksjon og artikkelforfattere har gjentatte ganger møtt kritikk fordi radiologen, patologen eller mikrobiologen ikke har vært involvert i utarbeidingen av artikkelen. Saken ble senest drøftet i spaltene høsten 2012 (1). I Tidsskriftet har vi nylig formulert en presisering på dette punktet: «Ofte vil det også være hensiktsmessig å involvere forfattere fra ulike faggrupper og institusjoner i utarbeidingen av manuskriptet» (2).

Hvordan kan redaksjonen, fagvurdererne og forfatterne bidra for å involvere relevante fagpersoner? Dette vil være et av temaene på Tidsskriftets årlige møte for faglige medarbeidere, som i år finner sted i Trondheim i mars. En representant for Norsk radiologisk forening vil delta i denne workshopen.

Vancouver-reglene inneholder bestemmelser om hvem som skal og hvem som ikke skal inngå i forfatterlisten til vitenskapelige artikler. Redaksjonen er klar over at forfatterskapsspørsmål er følsomme, men vi kan vanskelig overprøve forfatterne her og forutsetter at retningslinjene blir fulgt $(1,3)$. Spørsmålet er imidlertid verdt en diskusjon. Hvis man ikke oppfyller forfatterskapskriteriene, kan det f.eks. være rimelig å bli takket til slutt i artikkelen. Blir dette gjort i tilstrekkelig grad?

\section{Erlend Hem}

erlend.hem@medisin.uio.no

Erlend Hem (f. 1970) er dr.med. og konstituert sjefredaktør i Tidsskriftet.

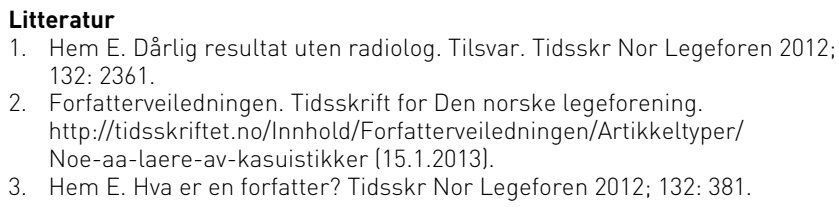

\section{RETTELSE}

Frøland utnevnt til ridder av St. Olavs Orden

Gunn Marit Seberg

Tidsskr Nor Legeforen 2012; 132: 2674

I Tidsskriftet nr. 23-24/2012 side 2674 skal overskriften og første setning lyde: Frøland utnevnt til kommandør av St. Olavs Orden. Stig Sophus Frøland (f. 1940) er utnevnt til kommandør av Den kongelige norske St. Olavs Orden.

Tredje avsnitt skal lyde: Frøland gikk av fra sin stilling som seksjonsoverlege ved Seksjon for klinisk immunologi og infeksjonsmedisin ved Oslo universitetssykehus, Rikshospitalet $i 2010$ og har fra da av vært professor emeritus ved Universitetet i Oslo. Han er en av Norges fremste aidseksperter.

Vi beklager feilene, de er rettet i nettutgaven. 